\title{
HUBUNGAN PENGETAHUAN DAN MOTIVASI IBU DENGAN PEMBERIAN MP-ASI DI WILAYAH KERJA PUSKESMAS RAWASARI KOTA JAMBI
}

\author{
Iin Indrawati ${ }^{1}$, Putri Qoriah Anggini ${ }^{2}$ \\ ${ }^{1}$ Program Studi D3 Keperawatan STIKes Baiturrahim Jambi \\ ${ }^{2}$ Program Studi D3 Kebidanan STIKes Baiturrahim Jambi \\ Email:iinian737497@gmail.com
}

\begin{abstract}
Prevalence of malnutrition in Indonesia 2013, consists of 5.7\% and $13.9 \%$ malnutrition. Giving breast milk too early may have a negative impact on the health of the baby. In infants who have missed the MP-ASI will lead to malnutrition. This research was conducted using the analytical method. The research was conducted in 2-14 September 2016. The population in this study were mothers of infants aged 6-11 months in Puskesmas Rawasari Jambi City in Agust 2016 that is 73 babies. The research sample is taken by simple random sampling technique totaling 42 babies. Collecting data in this study using a questionnaire measuring instrument with a questionnaire. The analysis used were univariate and bivariate. The results showed that most respondents had a good knowledge of 30 respondents (71\%), less well motivated as many as 25 respondents (40\%) and have good behavior, namely 23 respondents (55\%). The analysis showed that there is not a relationship between the mother's knowledge with the mother's habit of giving breast milk $p$ value 0,192.and motivationshowed that there is a relationship with the mother's habit of giving breast milk $p$ value 0,008 in that region Rawasari Work Puskesmas Kota Jambi.And alpha value 0.005.
\end{abstract}

Keywords: Awareness, Motivation Award MP ASI

\begin{abstract}
ABSTRAK
Prevalensi gizi di Indonesia tahun 2013 terdiri dari 5,7\% gizi buruk dan 13,9\% gizi kurang. Pemberian MP-ASI terlalu dini dapat memberikan dampak negatif terhadap kesehatan bayi. Pada bayi yang terlambat mendapatkan MP-ASI akan memicu terjadinya gizi kurang. Penelitian ini menggunakan metode deskriptif analitik. Waktu penelitian dilakukan tanggal 2 14 September 2016. Populasi adalah ibu dari bayi usia 6-11 bulan di Wilayah Kerja Puskesmas Rawasari berjumlah 73 bayi. Sampel diambil dengan teknik simple random sampling yang berjumlah 42 bayi. Pengumpulan data menggunakan kuesioner. Analisis yang digunakan adalah analisis univariat dan bivariat. Hasil penelitian menunjukkan bahwa 30 responden $(71 \%)$ memiliki pengetahuan baik, 25 responden $(40 \%)$ memiliki motivasi kurang baik dan 23responden (55\%) memiliki pemberian MP ASI yang baik. Hasil analisis tidak terdapat hubungan pengetahuan ibu dengan pemberian MP-ASI di Wiilayah Kerja Wilayah Kerja Puskesmas Rawasari Kota Jambi dengan p value 0,192. Terdapat hubungan motivasi ibu dengan pemberian MP-ASI dengan $p$ value 0,008 dan nilai alpha 0,05.
\end{abstract}

Kata Kunci: Pengetahuan, Motivasi pemberian MP ASI 


\section{PENDAHULUAN}

Angka Kematian Bayi (AKB) adalah indikator status kesehatan yang peka dalam menerangkan derajat kesehatan masyarakat.Salah satu masalah kesehatan utama di Indonesia adalah masih tingginya angka kematian bayi.Secara umum, kematian bayi dan anak dipengaruhi oleh faktor sosial ekonomi pada individu dan masyarakat. Variabel antara yang mempengaruhi kematian bayi meliputi faktor maternal dan kesehatan perorangan (Badriah, 2011) Berdasarkan hasil Riset Kesehatan Dasar (Riskesdas) tahun 2013 didapat hasil prevalensi gizi di Indonesia terdiri dari $5,7 \%$ gizi buruk dan $13,9 \%$ gizi kurang. Angka prevalensi gizi buruk meningkat dari 4,9\% pada tahun 2010 dan $5,7 \%$ tahun 2013. Sedangkan prevalensi gizi kurang naik sebesar $0,9 \%$ dari 2010 dan 2013 sebsear 13,9\%. Untuk mencapai sasaran MDGS tahun 2016 yaitu 15,5\% maka prevalensi gizi buruk-kurang secara nasional harus diturunkan sebesar $4.1 \%$ dalam periode 2013 sampai 2016 (Kemenkes RI, 2013).

Masalah gizi yang harus dihadapi Indonesia pada saat ini adalah masalah gizi kurang dan masalah gizi lebih.Masalah gizi kurang disebabkan oleh kemiskinan, kurangnya persediaan pangan, sanitasi lingkungan yang kurang baik, kurangnya pengetahuan masyarakat tentang gizi dan kesehatan, sedang masalah gizi lebih disebabkan oleh kemajuan ekonomi pada masyarakat disertai dengan kurangnya pengetahuan gizi dan kesehatan (Waryana, 2010).

Faktor utama yang paling mempengaruhi tumbuh kembang balita secara normal adalah asupan makanan yang kuantitas dan kualitasnya baik. Hal tersebut sangat bermanfaat bagi proses pertumbuhan dan perkembangan serta menjaga kesehatan upaya pencegahan beberapa penyakit atau masalah kesehatan (Badriah, 2011). Makanan pendamping ASI merupakan makanan tambahan bagi bayi.Makanan ini harus menjadi pelengkap dan dapat memenuhi kebutuhan bayi.Hal ini menunjukkan bahwa makanan pendamping ASI berguna untuk memenuhi kekurangan zat-zat gizi yang terkandung dalam ASI.Dengan demikian cukup jelas bahwa peranan makanan tambahan bukan sebagai pengganti ASI tapi untuk melengkapi atau mendampingi ASI (Waryana, 2010).

$$
\text { Menurut Pudjiadi (2000), }
$$
pemberian MP-ASI terlalu dini dapat mengganggu pemberian ASI eksklusif serta meningkatkan angka kesakitan pada bayi. Selain itu, tidak ditemukan bukti yang menyokong bahwa pemberian MPASI sebelum waktunya lebih menguntungkan. Bahkan sebaliknya, akan memberikan dampak negatif terhadap kesehatan bayi dan tidak ada dampak positif untuk perkembangan dan pertumbuhan bayi. Sedangkan bayi yang terlambat mendapatkan MP-ASI akan memicu terjadinya gizi kurang. MP-ASI yang baik tidak hanya cukup mengandung energi dan protein, tetapi juga mengandung zat besi, vitamin dan mineral.

\section{METODE PENELITIAN}

Penelitian ini dilakukan dengan menggunakan metode deskriptif analitik. Tujuan penelitian ini untuk mengetahui hubungan pengetahuan dan motivasi ibu dengan pemberian MP-ASI di Wilayah Kerja Puskesmas Rawasari Kota Jambi .Waktu penelitian dilakukan pada bulan September tahun 2016. Populasi dalam penelitian ini adalah ibu dari bayi usia 611 bulan di Wilayah Kerja Puskesmas Rawasari Kota Jambi bulan Agustus 
Tahun yang berjumlah 73 bayi. Sampel penelitian ini yaitu ibu yang memiliki bayi usia 6-11 bulan diambil dengan teknik simple random samplingyang berjumlah42 bayi. Pengumpulan data dalam penelitian ini menggunakan alat ukur kuesioner yang berisi pertanyaan pengetahuan, pernyataan otivasi dan pernyataan perilaku pemberian MP ASI.Analisis yang digunakan adalah analisis univariat dan bivariat.

\section{HASIL DAN PEMBAHASAN}

Penelitian ini bersumber dari data yang diperoleh melalui pengisian kuesioner terhadap 42 responden dengan menggunakan kuesioneruntuk mengetahui hubungan pengetahuan dan motivasi ibu dengan pemberian MP-ASI di Puskesmas Rawasari Kota Jambi.Pengumpulan data berlangsung pada bulan September 2016. Pengumpulan data dilakukan oleh peneliti sendiri yang dibantu oleh 1 orang enumerator mahasiswi STIKBA yang telah diberikan penjelasan mengenai cara penelitian.

Hasil penelitian dilakukan dengan analisis univariat yaitu dengan menyederhanakan atau memudahkan untuk menginterpretasi data kedalam bentuk penyajian secara tekstuler, tabuler dari distribusi variabel penelitian yang diteliti dan dianalisis bivariat untuk mengetahui hubungan pengetahuan dan motivasi ibu dengan pemberian MP-ASI.

Karakteristik responden berdasarkan umur, pendidikan, dan pekerjaandapat dilihat dari tabel berikut:

Tabel 1Distribusi

Responden

Berdasarkan Umur, Pendidikan dan

Pekerjaan di Wilayah Kerja Puskesmas Rawasari Tahun 2016

\begin{tabular}{llcc}
\hline No & \multicolumn{1}{c}{ Umur } & Jumlah & \% \\
& & & \\
1. & $20-35$ tahun & 38 & 90,5 \\
2. & $>35$ & 4 & 9,5 \\
\hline & Jumlah & 42 & 100 \\
\hline
\end{tabular}

Berdasarkan tabel 1. diketahui bahwa sebagian besar responden berusia 20-35 tahun sebanyak 38 responden $(90,5 \%)$,

Tabel 2. Distribusi Responden

Berdasarkan Pendidikan di Wilayah Kerja Puskesmas Rawasari Tahun 2016

\begin{tabular}{llcc}
\hline No & Pendidikan & Jumlah & $\%$ \\
\hline 1. & SD/Sederajat & 6 & 14,3 \\
2. & SMP/Sederajat & 5 & 11,9 \\
3. & SMA/sederajat & 28 & 66,7 \\
4. & Perguruan & 3 & 7,1 \\
& Tinggi \\
\hline & Jumlah & 42 & 100 \\
& Berdasarkan tabel & 2 & diketahui \\
bahwa sebagian besar berpendidikan \\
SMA/sederajat sebanyak & 28 responden \\
$(66,7 \%)$. &
\end{tabular}

Tabel 3.Distribusi Responden

Berdasarkan Pekerjaan di Wilayah Kerja Puskesmas Rawasari Tahun 2016

\begin{tabular}{clcc}
\hline No & Pekerjaan & Jumlah & \% \\
\hline 1. & IRT & 40 & 90,5 \\
2. & PNS & 1 & 4,8 \\
3. & Swasta & 1 & 4,8 \\
& Jumlah & 42 & 100 \\
\hline
\end{tabular}

Berdasarkan tabel 3 diketahui bahwa sebagian besartidak bekerja atau IRT yaitu sebanyak 47 responden $(92,3 \%)$. 
Gambaran Pengetahuan ibu terhadap pemberian MP-ASI di Puskesmas Rawasari Kota Jambi Tahun 2016

Pengetahuan dikategorikan menjadi dua yaitu baik jika jawaban benar $\geq 76 \%$ dan kurang baik jika jawaban benar $<76 \%$.Berdasarkan kategori tersebut pengetahuan pemberian MP-ASI dapat dilihat pada diagram 4 :

\section{Diagram 1 DistribusiPengetahuan}

Responden di Wilayah Kerja Puskesmas Rawasari Kota Jambi tahun 2016

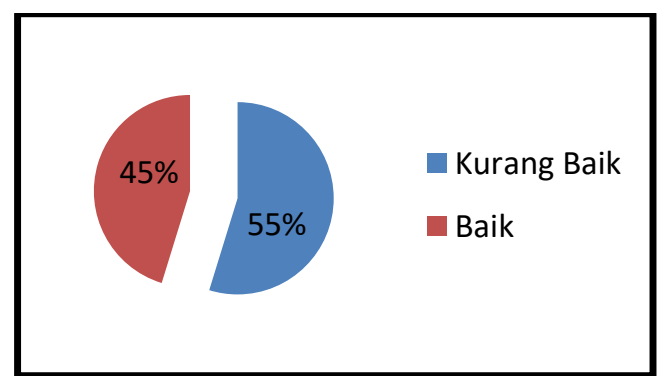

Berdasarkan diagram diatas dapat diketahui bahwa responden yang memiliki pengetahuanbaik yaitu 19 responden (45\%) dan responden yang memiliki pengetahuan kurang baik sebanyak 23 responden (55\%).

Gambaran Motivasi Ibu terhadap Pemberian MP-ASI di Wilayah Kerja Puskesmas Rawasari Kota Jambi Tahun 2016

Berdasarkan kategori tersebut motivasi ibu terhadap pemberian MP-ASI dapat dilihat pada tabel dibawah ini:

\section{Diagram 2}

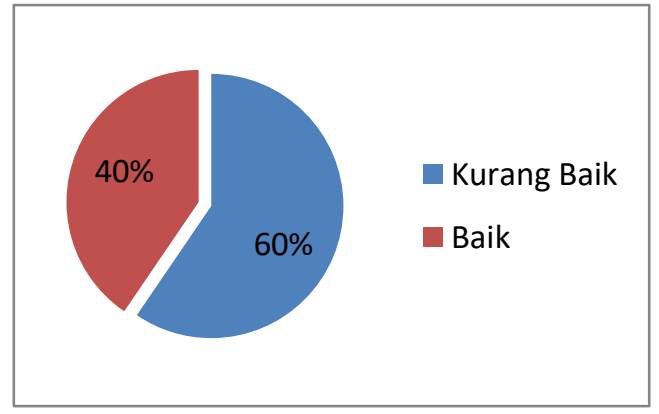

Berdasarkan diagram diatas dapat diketahui bahwa responden yang memiliki motivasi baik yaitu 17 responden $(60 \%)$ dan responden yang memiliki motivasi kurang baik sebanyak 25 responden $(40 \%)$.

Gambaran pemberian MP-ASI di Puskesmas Rawasari Kota Jambi Tahun 2016

Berdasarkan kategori tersebut pengetahuan pemberian MP-ASI dapat dilihat pada tabel dibawah ini:

Diagram 3 Distribusi Responden Berdasarkan Kategori PerilakuPemberian MP ASIdi Wilayah Kerja Puskesmas Rawasari Kota Jambi Tahun 2016

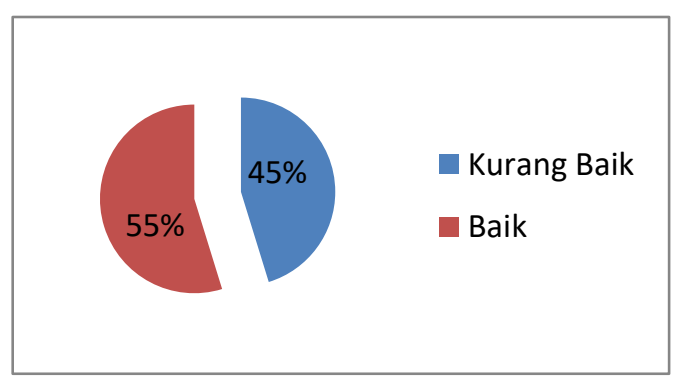

Berdasarkan diagram diatas dapat diketahui bahwa responden yang memiliki perilaku pemberian MP ASI baik yaitu 23responden (55\%) dan responden yang memiliki perilaku pemberian MP ASI kurang baik sebanyak 19 responden $(45 \%)$.

Hubungan Pengetahuan Ibu dengan Pemberian MP-ASI di Wiłoyahb Keriagesponden Berdasa Puskesmas Rawasari Kota Jambi Tahun 2016

Hasil menunjukkan bahwa dari 23 responden yang memiliki pengetahuan kurang baik $13 \quad(56,5 \%)$ responden memiliki perilaku yang kurang baik dan $10(43,5 \%)$ responden memiliki perilaku yang baik. Dari 19 responden yang 
memiliki pengetahuan baik $6(36,1 \%)$ responden memiliki perilaku kurang baik dan13 (68,4\%) responden memiliki perilaku yang baik.

$$
\text { Analisis }
$$

Chi Square

menunjukkan nilai $\mathrm{p}$-value $=0,192>0,05$ tidak ada hubungan bermakna antara pengetahuan ibu dengan pemberian MPASI di Wilayah Kerja Puskesmas Rawasari Kota Jambi Tahun 2016.

\section{Hubungan Motivasi Ibu dengan Pemberian MP-ASI di Wilayah Kerja Puskesmas Rawasari Kota Jambi Tahun 2016}

Hasil menunjukkan bahwa dari 25 responden yang memiliki motivasi kurang baik $16(64 \%)$ responden memiliki perilaku yang kurang baik dan 9 (36\%) responden memiliki perilaku yang baik. Dari 17 responden yang memiliki pengetahuan baik $3(17,6 \%)$ responden memiliki perilaku kurang baik dan14 $(82,4 \%)$ responden memiliki perilaku yang baik.

Analisis Chi Square menunjukkan nilai $\mathrm{p}$-value $=0,008<0,05$ berarti adahubungan bermakna antara motivasi ibu dengan pemberian MP-ASI di Wilayah Kerja Puskesmas Rawasari Kota Jambi Tahun 2016.

\section{Pembahasan}

Gambaran Pengetahuan Ibu Terhadap Pemberian MP-ASI Bulan di Wilayah Kerja Puskesmas Rawasari Kota Jambi Tahun 2016

Dari hasil penelitian yang diperoleh dapat dilihat bahwa responden yang memiliki pengetahuanbaik yaitu 19responden (45\%) dan responden yang memiliki pengetahuan kurang baik sebanyak 23 responden (55\%).

Hasil penelitianini tidak sejalan dengan hasil penelitian yang dilakukan oleh Hasil penelitian ini sejalan dengan hasil penelitian Nuranitha (2013) mengenai Hubungan Tingkat Pengetahuan ibu dengan Makanan Pendamping ASI bayi umur 7-11 Bulan di kecamatan Jatipuro Kabupaten Karanganyar didapat bahwa responden memiliki pengetahuan baik yaitu 74,3\%.Sedangkan hasil penelitian Dhymasandi (2013) mengenaiHubungan Pengetahuan Ibu Tentang Pemberian Makanan Pendamping ASI dengan Motivasi Memberikan Makanan Pendamping ASI Tepat Waktu di Desa Gayaman Mojoanyar Mojokerto. Hasil penelitian didapat bahwa sebagian besar responden mempunyai pengetahuan yang baik sebanyak $54,8 \%$.

Dalam penelitian ini, responden yang memiliki pengetahuan baik dipengaruhi oleh tingkat pendidikan responden dan informasi yang telah didapat oleh responden. Sedangkan responden yang memiliki pengetahuan kurang baik dikarenakan reponden kurang mendapatkan informasi mengenai MP ASI. Selain itu pengetahuan ibu yang kurang bisa dipengaruhi karena kurangnya keinginan ibu untuk mencari tahu atau melakukan konseling kepada petugas kesehatan.

Berdasarkan uraian diatas maka untuk membentuk pengetahuan ibu sangat dibutuhkan peran dari petugas kesehatan untuk selalu memberikan konseling pasca ibu melahirkan agar ibu dapat mengetahui kapan waktu pemberian MP-ASI, sehingga ibu dapat memberikan MP ASI sesuai pada waktunya.. Dengan informasi yang ibu dapat mengenai MP ASI akan menambah pengetahuan ibu dan memotivasi ibu untuk memberikan MP ASI dengan baik pada bayinya sehingga. Selain itu petugas dan dibantu oleh kader posyandu sebaiknya dapat meningkatkan penyuluhan mengenai MP-ASI yang dapat diberikan di posyandu saat bayi datang untuk imunisasi dan menimbang. 
Gambaran Motivasi Ibu Terhadap Pemberian MP-ASI di Wilayah Kerja Puskesmas Rawasari Kota Jambi Tahun 2016

Dari hasil penelitian yang diperoleh dapat dilihat bahwa responden yang memiliki motivasi baikyaitu 17responden $(60 \%)$ dan responden yang memiliki motivasi kurang baik sebanyak 25 responden $(40 \%)$.

Motivasi adalah suatu usaha yang disadari untuk mempengaruhi tingkah laku seseorang agar ia bergerak hatinya untuk bertindak melakukan sesuatu sehingga mencapai hasil dan tujuan tertentu (Notoatmodjo, 2010). Motivasi dipengaruhi oleh beberapa faktor yaitu faktor instrinsik dan faktor ekstrinsik.Yang dimaksud dengan motivasi instrinsik adalah motivasi yang berasal dari diri seseorang, sedangkan motivasi ekstrinsik berasal dari luar diri seseorang.Faktor instrinsik adalah pendidikan, pengalaman dan pengetahuan sedangkan faktor ekstrinsik adalah ekonomi, sosial budaya maupun lingkungan.

Dalam penelitian ini pengetahuan responden yang kurang baik mempengaruhi motivasi responden, karena banyak responden yang memiliki motivasi yang kurang baik terhadap pemberian MP ASI. Motivasi yangkurang baik tentang pemberian MP-ASI dapat diubah dan dibentuk dari kemauan ibu untuk mencari informasi mengenai MPASI serta diperlukan dukungan dari keluarga dan petugas kesehatan sehingga dengan adanya pengetahuan dan dukungan akan membentuk motivasi baik bagi ibu. Saran bagi petugas kesehatan untuk lebih meningkatkan pengetahuan ibu dengan membentuk kelas bayi dan balita dan memberikan penyuluhan serta demonstrasi mengenai cara pemberian MP ASI seperti jumlah pemberian MP
ASI, jenis makanan yang dapat diberikan pada anak, dan waktu pemberian MP ASI.

Gambaran Pemberian MP-ASI di Wilayah Kerja Puskesmas Rawasari Kota Jambi Tahun 2016

Dari hasil penelitian yang diperoleh dapat dilihat bahwa responden yang memiliki perilaku baik yaitu 23responden $(55 \%)$ dan responden yang memiliki perilaku kurang baik sebanyak 19 responden $(45 \%)$.

Makanan pendamping ASI adalah makanan atau minuman yang mengandung gizi diberikan kepada bayi atau anak untuk memenuhi kebutuhan gizinya (Ismawati, 2010). Pemberian Makanan pendamping ASI adalah makanan di luar ASI yang diberikan selama masa transisi dari ASI eksklusif menjadi makanan keluarga, biasanya dilakukan pada anak yang berusia 6 hingga 18 bulan sampai 24 bulan (Cadwell, 2011).

Hasil Penelitian sejalan dengan hasil penelitian yang dilakukan oleh Rohmatika (2011) mengenai Pemberian Makanan Pendamping ASI Bayi Di Posyandu Karyamulya Jetis Jaten didapat bahwa responden yang memberikan MPASI dengan tingkatan perilaku baik yaitu 86,7\%.Sedangkan hasil penelitian Dhymasandi (2013) mengenaiHubungan Pengetahuan Ibu Tentang Pemberian Makanan Pendamping ASI dengan Motivasi Memberikan Makanan Pendamping ASI Tepat Waktu di Desa Gayaman Mojoanyar Mojokerto.Hasil penelitian didapat bahwa sebagian besar responden mempunyai perilaku yang baik sebanyak $67 \%$.

Banyaknya kepatuhan responden dalam memberikan makanan pendamping ASI pada anaknya karena adanya pengetahuan responden yang baik dan disertai dukungan dari keluarga maupun 
petugas kesehatan yang mendorong ibu untuk memberikan makanan pendamping ASI pada usia yang tepat. Selain pengetahuan dan dukungan responden juga memiliki motivasi yang baik untuk mencari tahu mengenai kapan pemberian makanan pada anaknya melalui bertanya dengan keluarga maupun petugas kesehatan. Namun masih ada sedikit responden yang masih memberikan makanan pendamping ASI pada saat anaknya berusia kurang dari 6 bulan ini disebabkan ketidaktahuan ibu dan keluarga mengenai pemberian makanan pendamping ASI dengan tepat.

Dibutuhkan peran dari petugas kesehatan untuk lebih meningkatkan penyuluhan baik di Puskesmas maupun posyandu mengenai pemberian makanan pendamping ASI agar ibu yang memiliki bayi dapat memberikan MP-ASI pada usia yang tepat dan jenis makanan yang diberikan dibedakan berdasarkan usia masing-masing. Selain itu konseling mengenai MP-ASI sangat lebih baik apabila diberikan pasca bersalin atau saat ibu mulai mengimunisasikan anaknya.

\section{Hubungan Pengetahuan Ibu dengan Pemberian MP-ASI di Wilayah Kerja Puskesmas Rawasari Kota Jambi Tahun 2016}

Hasil analisis didapat bahwa nilai $\mathrm{p}$ value $0,192<0,05$ yang berarti tidak terdapat hubungan pengetahuan ibu dengan pemberian MP-ASI di Wilayah Kerja Puskesmas Rawasari Kota Jambi Tahun 2016.

Hasil penelitian ini berbeda dengan hasil penelitian Rohmatika (2011) Prodi mengenai "Hubungan Tingkat Pengetahuan Ibu dengan Pemberian Makanan Pendamping Asi Bayi Umur 624 Bulan Di Posyandu Karyamulya Jetis Jaten" didapat bahwa ada hubungan antara tingkat pengetahuan ibu dengan pemberian makanan pendamping ASI bayi umur 6-24 bulan.

Hasil analisis didapat bahwa dari 23 responden yang memiliki pengetahuan kurang baik $13(56,5 \%)$ responden memiliki perilaku yang kurang baik dan $10(43,5 \%)$ responden memiliki perilaku yang baik. Dari 19 responden yang memiliki pengetahuan baik $6(36,1 \%)$ responden memiliki perilaku kurang baik dan13 (68,4\%) responden memiliki perilaku yang baik.

Dalam penelitian ini pengetahuan responden tidak mempengaruhi perilakunya dalam pemberian ASI hal ini dapat terjadi karena pemberian MP ASI dapat dipengaruhi oleh faktor lain yaitu peran keluarga, petugas kesehatan, maupun motivasi ibu. Untuk meningkatkan pengetahuan terhadap pemberian MP ASI, maka dibutuhkan peran tenaga kesehatan untuk selalu meningkatkan pengetahuan masyarakat khususnya bagi ibu mengenai pentingnya MP-ASI melalui penyuluhan atau konseling di posyandu karena dan dengan meningkatnya pengetahuan masyarakat maka akan meningkatkan peran keluarga untuk memberikan dukungan dalam memberikan MP-ASI dengan baik.

\section{Hubungan Motivasi Ibu dengan Pemberian MP-ASI Pada Bayi 7-11 Bulan di Wilayah Kerja Puskesmas Rawasari Kota Jambi Tahun 2016}

Hasil analisis didapat bahwa nilai $p$ value $0,008<0,05$ yang berartiterdapat hubungan motivasi ibu dengan pemberian MP-ASI di Wilayah Kerja Puskesmas Rawasari Kota Jambi Tahun 2016. Dari hasil analisis diperoleh nilai $\mathrm{OR}=8,296$, artinya responden yang memiliki motivasi yang kurang baik mempunyai peluang 8,296 kali lebih besar untuk memiliki perilaku yang kurang baik dalam pemberian MP-ASI. 
Berdasarkan hasil penelitian didapat bahwa terdapat hubungan antara motivasi dengan pemberian MP-ASI.Hal ini menunjukkan bahwa, perilaku responden sehari-hari dipengaruhi motivasi dari dalam diri maupun dari luar untuk memberikan MP-ASI pada bayi.Dengan motivasi yang ada membuat responden memberikan MP-ASI yang baik pada bayinya.

Hasil penelitian ini sejalan dengan hasil penelitian Nuranitha (2013) mengenai Hubungan Tingkat Pengetahuan ibu dengan Makanan Pendamping ASI bayi umur 7-11 Bulan di kecamatan Jatipuro Kabupaten Karanganyar didapat bahwa ada hubungan motivasi dengan pemberian MP ASI dengan nilai $p$ value 0,004 .

Berdasarkan hasil penelitian terdapat $36 \%$ ibu yang memiliki motivasi kurang baik namun memberikan MP-ASI baik, pemberian MP-ASI bisa dipengaruhi oleh peran keluarga dan petugas kesehatan sehingga ibu memberikan MPASI dengan baik. Selain itu terdapat $17,6 \%$ responden yang memiliki motivasi baik namun memberikan MP-ASI dengan kurang baik hal ini bisa dipengaruhi kurangnya dukungan dari keluarga untuk membantu ibu memberikan MP ASI.

Dapat diketahui bahwa dalam hal ini motivasi responden mempengaruhi perilaku responden untuk memberikan MP ASI. Maka dari itu untuk meningkatkan pemberian MP-ASI dengan baik tidak hanya dibutuhkan motivasi yang baik namun dibutuhkan pengetahuan dan motivasi dari dalam diri untuk memberikan MP-ASI dengan baik dan tepat waktu. Selain itu sangat dibutuhkan peran dari tenaga kesehatan untuk terus mendorong ibu khusunya pada masa pasca melahirkan untuk memberikan MPASI pada bayi dengan tepat waktu. Dukungan keluarga juga dibutuhkan untuk mendukung dan membantu ibu dalam memberikan MP-ASI dengan baik.

Selain itu untuk meningkatkan motivasi ibu sebaiknya petugas kesehatan lebih meningkatkan pengetahuan ibu dengan mengadakan penyuluhan serta melakukan demonstrasi untuk mempraktekkan cara pemberian MP ASI.

\section{SIMPULAN}

1. Sebagian responden (55\%)memiliki perilaku pemberian MP-ASI yang baik.

2. Sebagianresponden (55\%)memiliki pengetahuanbaik tentang pemberian MP-ASI..

3. Sebagian respondenresponden (60\%)memiliki motivasi kurang baik dalam pemberian MP-ASI.

4. Tidak ada hubungan pengetahuan dengan pemberian MP-ASI dengan $\mathrm{p}$ value 0,192

5. Ada hubungan motivasi ibu dengan pemberian MP-ASI dengan nilai $\mathrm{p}$ value 0,008 .

\section{SARAN}

Saran bagi petugas kesehatanagar dapat meningkatkan penyuluhan dan sosialisasi tentang pentingnya pemberian MP ASI dengan membentuk kelas bayi dan balita untuk memberikan penyuluhan dan demonstrasi khususnya mengenai jumlah pemberian MP ASI, jenis makanan dan waktu pemberian MP ASI.

\section{.DAFTAR PUSTAKA}

Badriah, Dewi, L, Gizi Dalam Kesehatan Reproduksi. Refika Aditama. Jakarta

Baskoro, A. 2008. ASI Panduan Praktis Ibu Menyusui. Jogjakarta: Banyu Media Dinas Kesehatan Kota Jambi. 2014. Profil Kesehatan Kota Jambi 2014. KotaJambi. 
Elya, Eva, S, 2010.Gizi Dalam Kesehatan Reproduksi. Trans Info Medika. Jakarta

Ismawati, Cahyo. 2010. Posyandu dan Desa Siaga. Nuha Medika. Yogyakarta.

Kemenkes RI, 2012. Survey Demografi Kesehatan Indonesia Tahun 2012. Jakarta.

Kemenkes RI, 2013. Riset Kesehatan Dasar Tahun 2013. Badan Penelitian dan Pengembangan Kesehatan. Jakarta

Maryunani, Anik. Ilmu Kesehatan Anak Dalam Kebidanan. Trans Info Media. Jakarta

Nuranitha. 2013. Hubungan Tingkat Pengetahuan dan Motivasi ibu dengan Makanan Pendamping ASI bayi umur 711 Bulan di kecamatan Jatipuro Kabupaten Karanganyar. Jurnal Universitas Muhamadiyah. Surakarta.

Pudjiadi. S. 2000. Ilmu Gizi Klinis Pada Anak. Edisi Keempat FKUI. Jakarta. Sulistyoningsih, 2011. Gizi Untuk Kesehatan Ibu dan Anak. Graha Ilmu. Yogyakarta.

Waryana, 2010. Gizi Reproduksi. Pustaka Rihama. Yogyakarta.

Wawan, A. 2010. Teori dan Pengukuran Pengetahuan, Sikap dan Perilaku Manusia. Nuha Medika. Yogyakarta. 